\title{
Influencia de la temperatura de curado sobre la evolución de las resistencias a compresión de hormigones fabricados con distintos tipos de cementos
}

\author{
Influence ot the curing temperatures on the evolution \\ of the compression strength of concretes made with \\ different typer of cements
}

MANUEL FERNANDEZ CANOVAS ( $\left.{ }^{*}\right)$

ESPAÑA

Fecha de recepción: 7-II-91

RESUMEN

En este trabajo se presentan los resultados obtenidos en un estudio sobre la evolución de las resistencias a compresión de hormigones idénticos confecciondados con distintos tipos de cementos de la norma española UNE 80 301 cuando son sometidos a temperaturas extremas de curado ( $5^{\circ} \mathrm{C}$ y $35^{\circ} \mathrm{C}$ ), comparándola con la de los mismos hormigones curados en condiciones normalizadas a $20^{\circ} \mathrm{C}$.

El número de cementos distintos empleados ha sido de ocho.

El comportamiento de estos hormigones se ha analizado a través de los resultados de las resistencias a compresión a $3,7,14,28$ y 90 dias, determinándose los grados de madurez relativos de los hormigones sometidos a las diferentes temperaturas.

Del trabajo se concluye que los hormigones en los que se emplean diferentes tipos de cementos cumplen perfectamente con las previsiones en cuanto a sus resistencias a 28 días.

\begin{abstract}
$S \cup M M A R Y$
In this paper we present the results obtained in the studies carried out on evolution of the compressive strength of identical concretes made with different types of cements based on the spanish standard UNE 80301 when they are subjected to critical temperatures $\left(5^{\circ} \mathrm{C}\right.$ and $\left.35^{\circ} \mathrm{C}\right)$, compared with the same concretes cured under normalysed conditions.
\end{abstract}

The number of the different cements used was eight.

The behaviour of the concretes was analysed through the results of the compression strengths at 3, 7, 14, 28 and 90 days, determining the grades of relative maturity of these concretes subjerted to the different temperatures.

From the work it can be concluded that these concretes made of different cements fulfill with their forecasted strength at 28 days.

\section{OBJETO DEL ESTUDIO}

Coincidiendo con la aparición en España de los nuevos tipos de cementos definidos y clasificados en la norma UNE 80301 el Laboratorio de la Cátedra de Materiales de la ETS de Ingenieros de Caminos, Canales y Puertos de Madrid inició un estudio destinado a conocer la evolución en el

\section{AIM OF THE STUDY}

Coinciding with the appearance of new types of cements in Spain defined and classified in the standard UNE 80 301, the Laboratory of Materials of the Departament of Construction of the ETS of Ingenieros de Caminos, Canales y Puertos of Madrid, iniciated a study aimed at knowing the

(*) Director del Departamento de Construcción. ETS de Ingenieros de Caminos. Universidad Politécnica de Madrid. 
tiempo de la resistencia a compresión de hormigones idénticos confeccionados con distintos tipos de cementos recogidos en la anterior norma, cuando por razones climáticas de la obra tienen que curarse a temperaturas diferentes a la del curado normalizado a $20^{\circ} \mathrm{C}$.

La incorporación de adiciones en proporciones muy variadas al clinker portland para formar los distintos tipos de cementos es lógico que produzca alteraciones en la evolución de las resistencias con la edad, toda vez que estas adiciones, por su naturaleza, son menos reactivas que el cemento portland puro; por otra parte, la reactividad es función de la temperatura y hay que tener en cuenta que las obras no están a la temperatura de la cámara normalizada de curado sino que ésta puede ser muy variable influyendo, por tanto en la evolución de resistencias, unas veces de forma positiva y otras negativa según que las temperaturas sean altas o bajas.

Para tener en cuenta todos estos efectos se han elegido ocho cementos con distintos tipos de adiciones $y$ en distintas proporciones, realizándose el estudio para las temperaturas extremas de $35^{\circ} \mathrm{C}$ (para caso de verano) y de $5^{\circ} \mathrm{C}$ (para invierno) y para la temperatura normalizada de $20^{\circ} \mathrm{C}$ que se ha tomado como referencia.

\section{CEMENTOS Y HORMIGONES EMPLEADOS}

Los cementos empleados en el estudio se han elegido entre los clasificados en la norma UNE 80 301 buscanto tener una buena representatividad de los mismos. Los cementos elegidos son los de los tipos y categorías que se indican a continuación:
1. Cemento I-45A
2. Cemento IIF-35.
3. Cemento IIS-35.
4. Cemento IIC-35.
5. Cemento III-1-35.
6. Cemento III-1-45.
7. Cemento V-35(*).
8. Cemento V-25("*).

(*) Cemento con 40 por 100 de adición de cenizas volantes.

(**) Cemento con 60 por 100 de adición de cenizas volantes. time evolution of the compression strength of identical concretes made with different cements gathered in the previous standard when for climatical reasons they have to be cured on the site under different temperatures from the normalysed of $20^{\circ} \mathrm{C}$.

The incorporation of additives in the portland clinker at variable proportions during the preparation of different types of cements will logically produce some alterations in the strength evolution in relation to age, as a consecuence that additives, for their nature, are less reactives than the pure portland cement and on the other hand their reactivity is a funtion of time and it is necessary to have in mind that at the site of construction the temperatures are not, the same as those of the normalised curing chamber but very variables, thus affecting the strength evolutions sometimes positively and another time negatively depending on whether the temperatures are high or low.

In other to take in consideration all these effects eight cements with differents types of additives in different proportions were sellected, the study was carried out at extreme temperatures of $35^{\circ} \mathrm{C}$ (case of summer) and of $5^{\circ} \mathrm{C}$ (case of winter) and at normalysed temperature of $20^{\circ} \mathrm{C}$ which was taken as a refference.

\section{CEMENTS AND CONCRETES USED}

The cements used in is study were sellected from those classified in the standard UNE 80301 searching for a good representation of them. The cements sellected are the types and classes presented below:

\section{Cement $1-45 A$.}

2. Cement IIF-35.

3. Cement IIS-35.

4. Cement IIC-35.

5. Cement III-1-35.

6. Cement III-1-45.

7. Cement V-35(*).

8. Cement V-45("*).

(*) Cement with $40 \%$ of fly ash as additive.

(**) Cement with $60 \%$ of fly ash as additive. 
Los cementos empleados fueron ensayados y una parte de los ensayos físicos tales como las resistencias a flexotracción y compresión a las edades de $3,7,14,28$ y 90 días se reproducen a continuación. Los ensayos se hicieron de acuerdo con las normas y sobre probetas de $4 \times 4 \times 16 \mathrm{~cm}$.
All the cements used were tested according with the actual standards on flexural and compression in order to determinate their stregths at the ages of $3,7,14,28$ and 90 days. In the tests $4 \times 4 \times$ $16 \mathrm{~cm}$ speciments were used. The results of the tests were the following:

TABLA 1 TABLE 1

\begin{tabular}{|c|c|c|c|c|c|}
\hline \multirow{3}{*}{$\begin{array}{l}\text { CEMENTO TIPO } \\
\text { (CEMENT TIPE) }\end{array}$} & \multicolumn{5}{|c|}{$\begin{array}{l}\text { RESISTENCIA A FLEXOTRACCION }\left(\mathrm{N} / \mathrm{mm}^{2}\right) \\
\text { [FLEXURAL OF STRENGTH }\left(\mathrm{n} / \mathrm{mm}^{2}\right) \text { ] }\end{array}$} \\
\hline & \multicolumn{5}{|c|}{ EDAD (días) [AGE (days)] } \\
\hline & 3 & 7 & 14 & 28 & 90 \\
\hline $145-A$ & 5.1 & 6.1 & 6.8 & 7.4 & 8.6 \\
\hline IIF-35 & 5.5 & 6.1 & 6.8 & 7.5 & 8.1 \\
\hline IIS-35 & 4.9 & 6.0 & 6.5 & 7.3 & 7.9 \\
\hline IIC-35 & 4.0 & 4.7 & 6.4 & 6.8 & 7.5 \\
\hline III-1-35 & 3.9 & 4.9 & 7.3 & 9.1 & 9.4 \\
\hline$|I|-1-45$ & 3.8 & 5.8 & 6.5 & 7.2 & 9.1 \\
\hline V-35 & 4.1 & 4.9 & 6.8 & 7.9 & 8.6 \\
\hline$V-25$ & 2.7 & 3.4 & 4.3 & 5.4 & 7.1 \\
\hline
\end{tabular}

TABLA 2 TABLE 2

\begin{tabular}{|c|c|c|c|c|c|}
\hline \multirow{3}{*}{$\begin{array}{l}\text { CEMENTO TIPO } \\
\text { (CEMENT TIPE) }\end{array}$} & \multicolumn{5}{|c|}{$\begin{array}{l}\text { RESISTENCIA A COMPRESIÓN }\left(\mathrm{N} / \mathrm{mm}^{2}\right) \\
\text { [COMPRESSIVE OF STRENGTH }\left(\mathrm{N} / \mathrm{mm}^{2}\right) \text { ] }\end{array}$} \\
\hline & \multicolumn{5}{|c|}{ EDAD (dias) [AGE (days)] } \\
\hline & 3 & 7 & 14 & 28 & 90 \\
\hline $145-A$ & 33.8 & 41.4 & 43.6 & 49.5 & 54.7 \\
\hline IIF-35 & 37.3 & 40.4 & 46.7 & 53.0 & 57.9 \\
\hline IIS-35 & 29.8 & 36.9 & 41.7 & 47.6 & 56.5 \\
\hline IIC-35 & 22.4 & 30.1 & 38.8 & 43.5 & 52.0 \\
\hline III-1-35 & 16.9 & 22.2 & 34.4 & 43.4 & 51.9 \\
\hline III-1-45 & 23.7 & 33.7 & 41.2 & 48.1 & 58.9 \\
\hline V-35 & 16.6 & 19.7 & 29.7 & 38.5 & 47.0 \\
\hline V-25 & 14.6 & 17.5 & 29.5 & 30.2 & 43.9 \\
\hline
\end{tabular}


Los hormigones empleados en el estudio tenían dosificaciones de cemento de 350 y $275 \mathrm{~kg} / \mathrm{m}^{3}$ y en unos se empleaban áridos rodados silíceos de $40 \mathrm{~mm}$ de tamaño máximo y en otros áridos machacados calizos del mismo tamaño máximo. En todos los hormigones la arena utilizada ha sido silícea de río. La cantidad de agua empleada ha sido la precisa para conseguir en todos los hormigones una consistencia, medida con el consistómetro de $\mathrm{VeBe}$, comprendida entre 4 y $6 \mathrm{~s}$.

Las dosificaciones por metro cúbico de los hormigones han sido las siguientes:

\section{Hormigón tipo 1}

\section{Cemento}

Arena 0/5 mm

Arido (rodado o machacado) $5 / 20 \mathrm{~mm}$.

Arido (rodado o machacado) $20 / 40 \mathrm{~mm}$.

Agua
The concretes used in this study had a cement dosis of $350 \mathrm{~kg} / \mathrm{m}^{3}$ and $275 \mathrm{~kg} / \mathrm{m}^{3}$ and in one of them round silica aggregates were used and in the others crushed limestone aggregates. Both aggregates had a maximum size of $40 \mathrm{~mm}$. All the concretes used a river sand aggregate. The amount of water used was the exact necessary to have a consistence VeBe between 4 and $6 \mathrm{~s}$.

The mixing proportions per cubic meter of concrete were the following:

\section{Concrete type 1}

Cement

Sand 0/5 $\mathrm{mm}$.

Aggregate (round or crushed) $5 / 20 \mathrm{~mm}$. Aggregate (round or crushed) $20 / 40 \mathrm{~mm}$. Water

$$
\begin{array}{r}
350 \mathrm{~kg} / \mathrm{m}^{3} \\
675 \mathrm{~kg} / \mathrm{m}^{3} \\
675 \mathrm{~kg} / \mathrm{m}^{3} \\
550 \mathrm{~kg} / \mathrm{m}^{3} \\
X \quad \mathrm{l} / \mathrm{m}^{3}
\end{array}
$$

\section{Hormigón tipo 2}

Cemento

Arena $0 / 5 \mathrm{~mm}$.

Arido (rodado o machacado) $5 / 20 \mathrm{~mm}$. Arido (rodado o machacado) $20 / 40 \mathrm{~mm}$. Agua

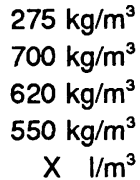

En las dosificaciones anteriores la cantidad de agua a emplear $X$ ha sido variable puesto que, como se ha indicado anteriormente, con cada hormigón se ha empleado el agua necesaria, determinada mediante masas de prueba, para conseguir que la consistencia correspondiese a un tiempo VeBe comprendido entre 4 y $6 \mathrm{~s}$. Esto motivó el que la relación agua/cemento de los distintos hormigones fabricados haya sido diferente no sólo como consecuencia de los dos tipos de áridos empleados sino también de los diferentes cementos utilizados e incluso de la distinta dosificación de los mismos.

Aunque los cuatro tipos de hormigones anteriores se han empleado en el estudio vamos a reducir la presentación en este trabajo al tipo 1 realizado con áridos rodados debido a que sería imposible por limitaciones de espacio el poder presentar los resultados de todos los hormigones máxime si se tiene en cuenta que la realización de este estudio ha supuesto el ensayo de 2.500 probetas cilíndricas de tamaño normal. Por otra parte, no se ha considerado importante el presentar el comportamiento de los otros tres hormigones dado que éste ha sido muy similar al del hormigón 1 que presentamos y a que no ha habido discrepancias notables.

\section{Concrete type 2}

Cement

Sand $0 / 5 \mathrm{~mm}$.

Aggregate (round or crushed) $5 / 20 \mathrm{~mm}$.

Aggregate (round or crushed) $20 / 40 \mathrm{~mm}$.

Water

$275 \mathrm{~kg} / \mathrm{m}^{3}$ $700 \mathrm{~kg} / \mathrm{m}^{3}$ $620 \mathrm{~kg} / \mathrm{m}^{3}$ $550 \mathrm{~kg} / \mathrm{m}^{3}$

X $1 / \mathrm{m}^{3}$

In the former concrete mixes the $X$ amount of water used were variable because as it has been indicated before in every concrete the water was the neccesary, determinated through masses of experiments so as to obtain a consistence corresponding to $\mathrm{VeBe}$ time within 4 and $6 \mathrm{~s}$. This made the water/cement ratio of the various concretes be different not only as a result of the two types of aggregates used but also for the different cements used including their different mixes.

Although the four former types of concretes have been used in this study, we are going to reduce the presentation of the work to type 1 made with round silica aggregate because the limitation of space has made impossible to present the results of all concretes particularly if we have in mind that the achievement of this study asumed a test of 2.500 normal size cylindrical speciments. Moreover, it was not considered important to present the behaviour of the others three concretes given that this had been very similar and without notable discrepancy to the concrete 1 which we present. 
Las relaciones agua/cemento para los hormigones fabricados con $350 \mathrm{~kg} / \mathrm{m}^{3}$ de cada uno de los cementos y con áridos rodados han sido las que se indican a continuación.
The water/cement ratios for the concrete of 350 $\mathrm{kg} / \mathrm{m}^{3}$ of cement corresponding to every one of the cements used and round silica aggregates were the following:

TABLA 3 TABLE 3

\begin{tabular}{|c|c|}
\hline $\begin{array}{c}\text { CEMENTO } \\
\text { (CEMENT) }\end{array}$ & $\begin{array}{c}\text { RELACION A/C } \\
\text { (RELATION A/C) }\end{array}$ \\
\hline I-45A & 0.457 \\
IIF-35 & 0.435 \\
IIS-35 & 0.457 \\
IIC-35 & 0.470 \\
III-1-35 & 0.457 \\
III-1-45 & 0.457 \\
V-35 & 0.425 \\
V-25 & 0.420 \\
\hline
\end{tabular}

\section{FABRICACIÓN DE HORMIGONES}

Los hormigones empleados en este estudio se han dosificado en peso y se han amasado en una hormigonera planetaria adicionando el agua precisa hasta conseguir la consistencia requerida.

Con cada dosificación se han confeccionado veinte probetas cilíndricas de $15 \times 30 \mathrm{~cm}$ para romper a compresión en grupos de cuatro probetas a las edades de $3,7,14,28$ y 90 días.

El hormigón se ha compactado en una mesa vibrante de 6.000 c.p.m. controlando el tiempo de vibración.

Las probetas se han conservado en una cámara de curado ajustada a la temperatura prevista de conservación hasta la edad de rotura a la que eran extraídas de la misma cuatro horas antes de su ensayo y dejadas en ambiente de laboratorio. Todas las probetas se refrentaron con azufre antes de su rotura.

Las temperaturas de curado han sido de $5^{\circ}, 20^{\circ} \mathrm{y}$ $35^{\circ} \mathrm{C}$ con un error de $1^{\circ} \mathrm{C}$. La humedad relativa en el interior de la cámara ha oscilado entre el 95 y 98 por 100 .

\section{RESULTADOS OBTENIDOS}

Los resultados de los ensayos a compresión a las edades que se han indicado anteriormente y para las tres temperaturas de curado aparecen recogidos en los ocho gráficos que se acompañan.

\section{FABRICATION OF THE CONCRETES}

The mixes of concretes used in this study were based on weight and batched in a planetary concrete mixer adding an exact amount of water to obtain the required consistence.

With every mix twenty $15 \times 30 \mathrm{~cm}$ cylindrical speciments were made to be tested on compression in groups of four speciments at the ages of $3,7,14,28$ and 90 days.

The concrete was compacted on a vibratory table of 6.000 c.p.m. controlling the vibration time.

The speciments were conserved in a curing chamber adjusted to the conservation temperature rated up to the age of test at which they were taken out four hours before their test and left at laboratory enviroment conditions. All the speciments were capped with sulphur before their test.

The curing temperatures were $5^{\circ} \mathrm{C}, 20^{\circ} \mathrm{C}$ and $35^{\circ} \mathrm{C}$ with an error of $1^{\circ} \mathrm{C}$. The relative humedity inside the chamber oscilated between 95 and 98 per 100.

\section{RESULTS OBTAINED}

The results of the compression tests correspond to the ages indicated before and to the three curing temperatures appear collected in the eigth enclosed graphics. 

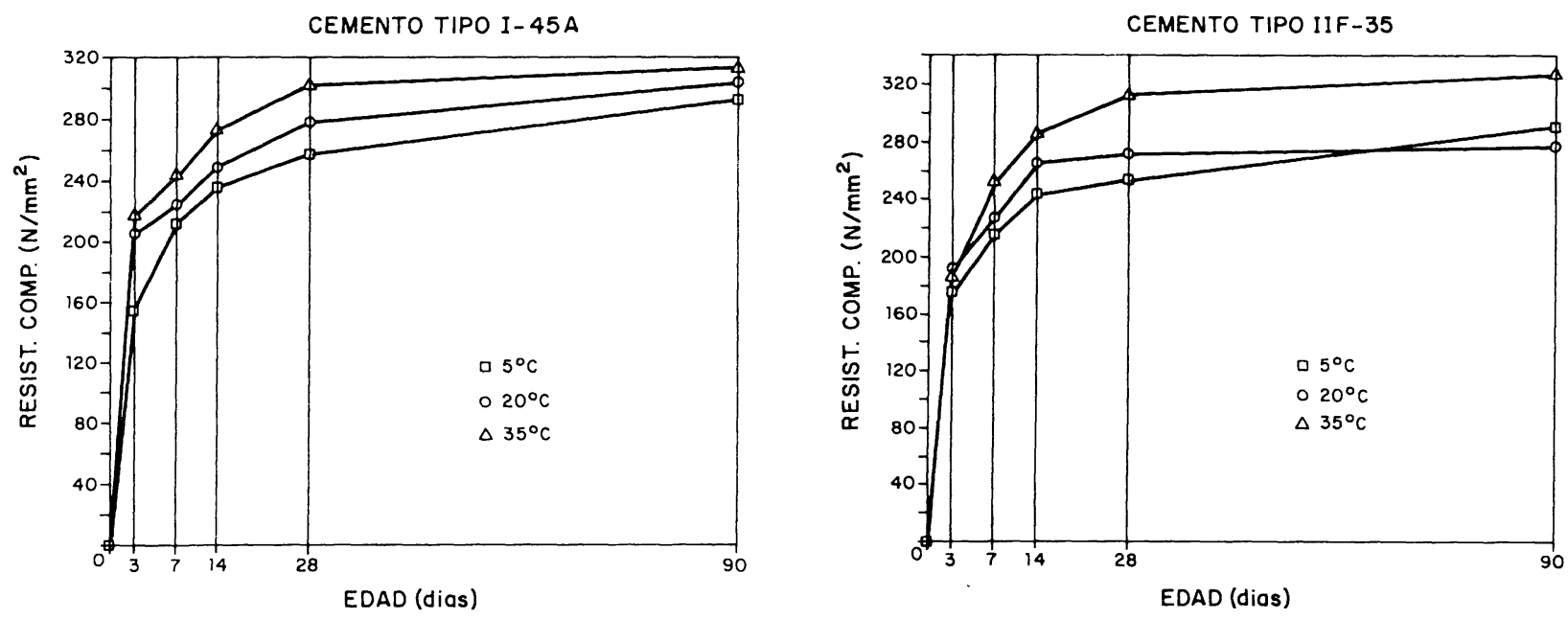

Gráfico 1
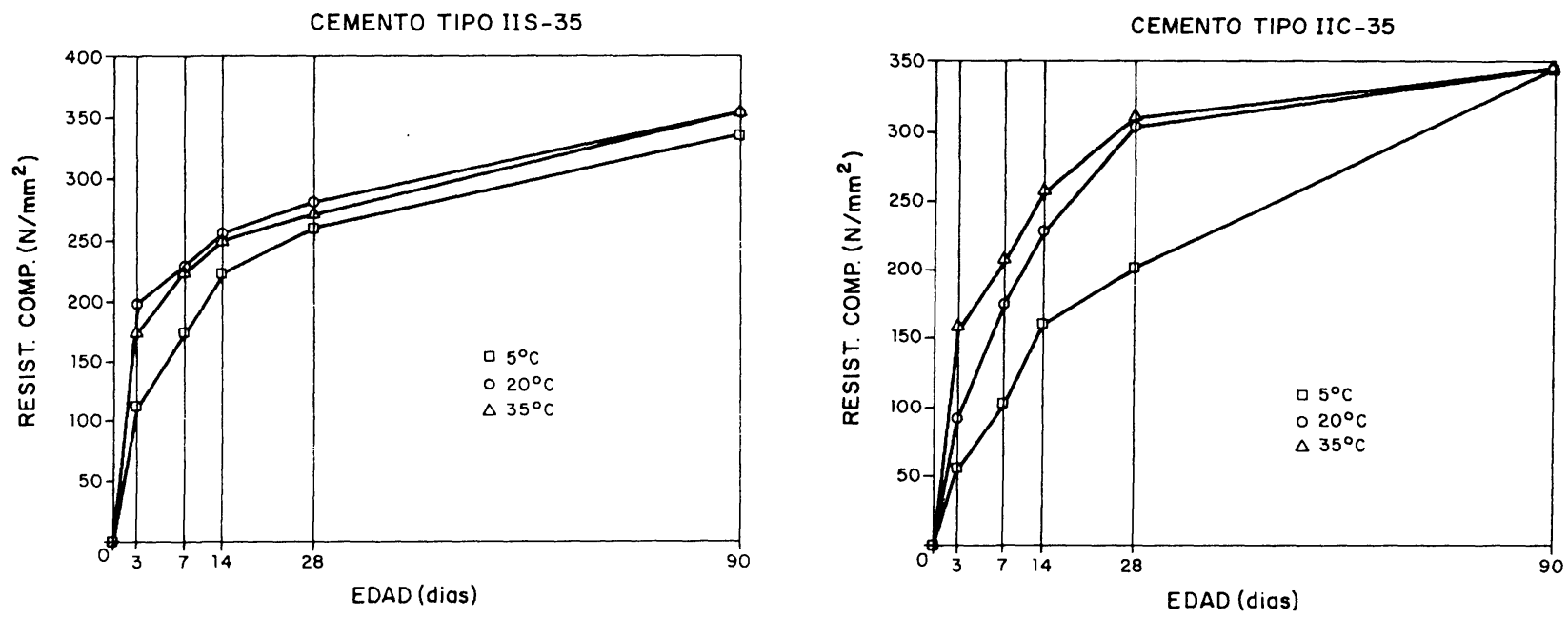

Gráfico 2
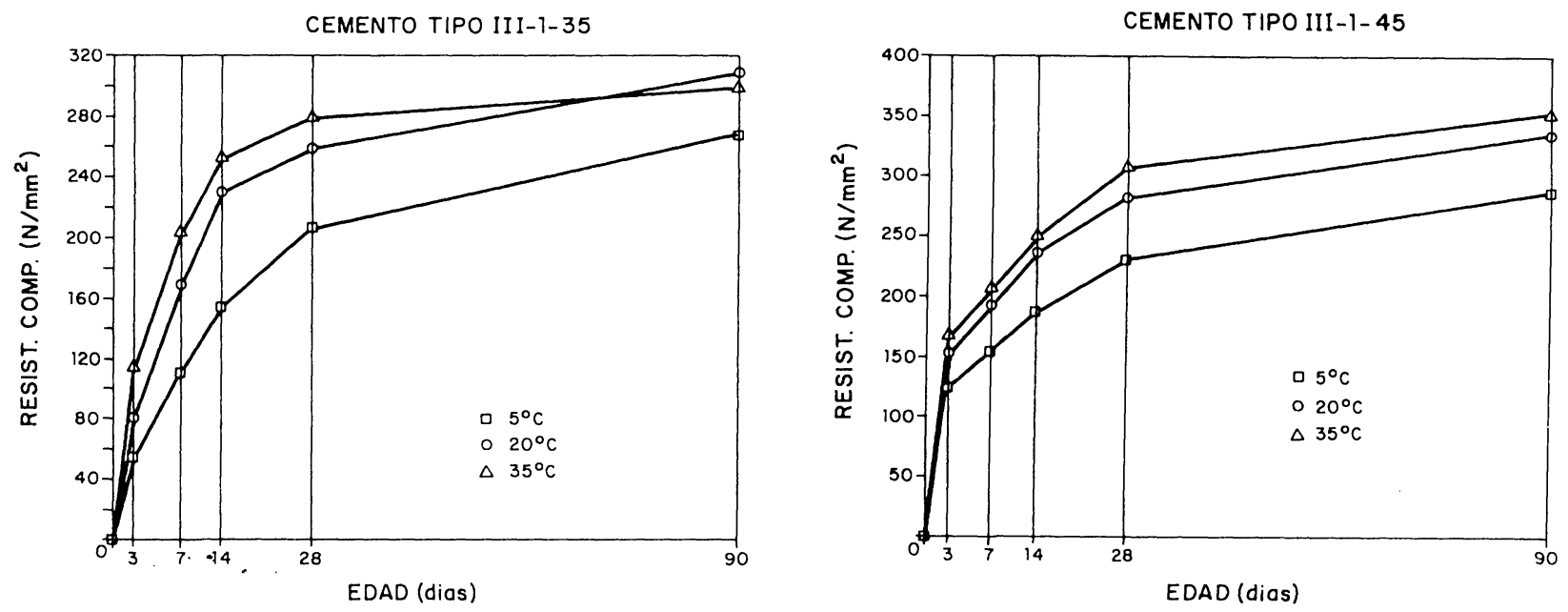

Gráfico 3 

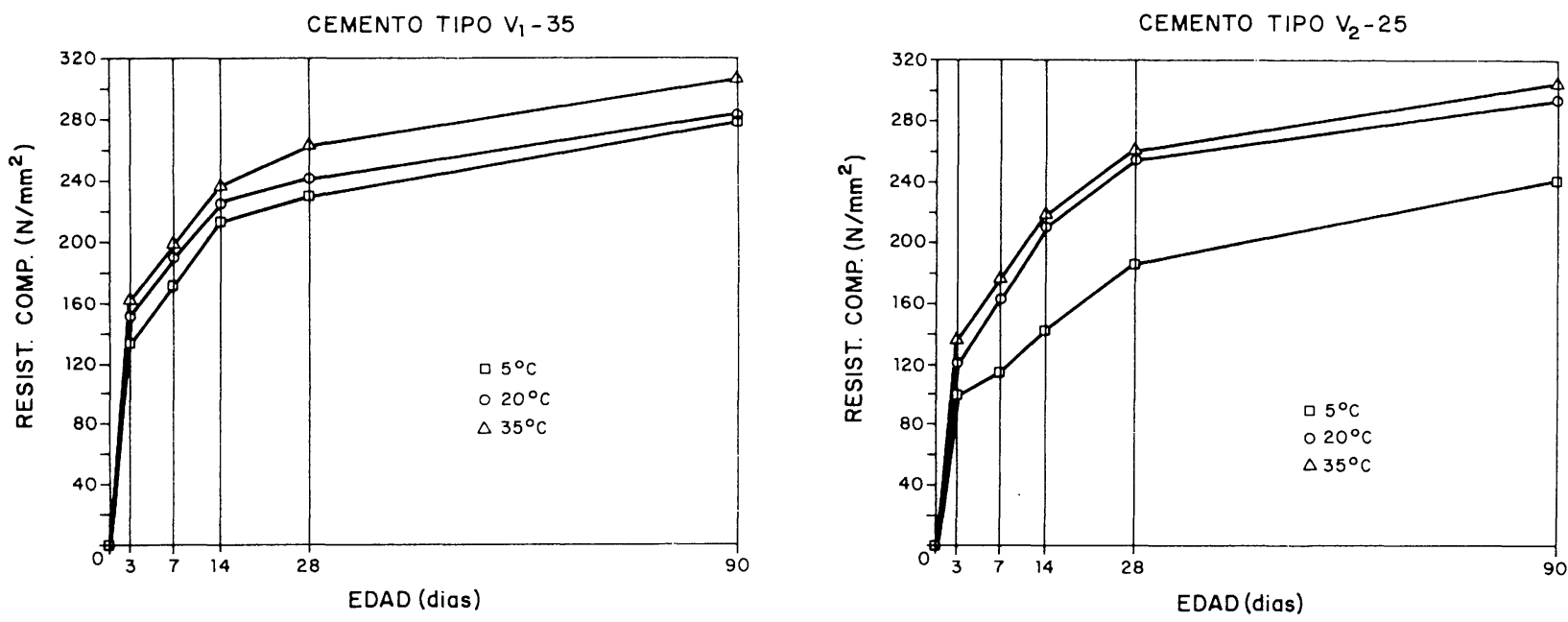

Gráfico 4

\section{MADUREZ PORCENTUAL RELATIVA}

Dado que los diferentes hormigones fabricados con los distintos cementos se han curado, aunque en condiciones diferentes de temperatura, en atmósfera saturada de humedad, es posible aplicar a los mismos los criterios de madurez dados por la expresión:

$$
R=t(T+10)
$$

en la que:

$R$, es el grado de madurez en $h^{\circ} \mathrm{C}$,

$t$, es el tiempo en horas,

$\mathrm{T}$, es la temperatura en ${ }^{\circ} \mathrm{C}$.

Se ha tomado como madurez de comparación la de los hormigones fabricados con los distintos cementos y curados a la temperatura de $20^{\circ} \mathrm{C}$ por ser ésta la temperatura normalizada. Los valores porcentuales hallados que figuran en el cuadro siguiente permiten observar cómo evoluciona la madurez de los hormigones fabricados con los distintos cementos estudiados cuando están sometidos a unas condiciones de temperatura diferentes a las normalizadas como, por otra parte, es frecuente que ocurra en obra.

\section{RELATIVE PERCENTAGE MATURITY}

Given that the various concretes fabricated with different cements have been cured, although in different conditions of temperature, in humidity air saturated, it is possible to apply the same criterium of maturity given by the expression:

$$
R=t(T+10)
$$

where:

$R$, is the maturity in $h^{\circ} C$,

$t$, is the time in hours, and

$T$, is the temperature in ${ }^{\circ} \mathrm{C}$.

The maturity of concretes fabricated with different cements and cured at a temperature of $20^{\circ} \mathrm{C}$ has been taken as a refference because this is the normalysed temperature. The percentage values obtained and which appears in the following table allows us to observe the maturity evolution of the concretes made of the different cements studied after they have been subjected to some conditions of temperatures different from the normalysed one, as it frequently occures at the place of construction. 
TABLA 4 TABLE 4

\begin{tabular}{|c|c|c|c|c|c|c|}
\hline \multirow{3}{*}{$\begin{array}{l}\text { HORMIGO: } \\
\text { (CONCRETE) } \\
\text { Cemento } \\
\text { tipo } \\
\text { (Type } \\
\text { cement) }\end{array}$} & \multicolumn{6}{|c|}{$\begin{array}{l}\text { MADUREZ RELATIVA (\%) } \\
\text { (RELATIVE MATURITY \%) }\end{array}$} \\
\hline & \multicolumn{6}{|c|}{ EDAD (días) [AGE, (days)] } \\
\hline & 0 & 3 & 7 & 14 & 28 & 90 \\
\hline $\mathrm{I}-45 \mathrm{~A}$ & $\begin{array}{l}0.0 \\
0.0 \\
0.0\end{array}$ & $\begin{array}{l}54.2 \\
74.1 \\
78.9\end{array}$ & $\begin{array}{l}77.6 \\
80.0 \\
87.9\end{array}$ & $\begin{array}{l}86.3 \\
89.5 \\
99.9\end{array}$ & $\begin{array}{r}93.3 \\
100.0 \\
109.6\end{array}$ & $\begin{array}{l}106.0 \\
109.7 \\
113.2\end{array}$ \\
\hline IIF-35 & $\begin{array}{l}0.0 \\
0.0 \\
0.0\end{array}$ & $\begin{array}{l}63.6 \\
69.8 \\
67.4\end{array}$ & $\begin{array}{l}79.1 \\
82.8 \\
91.3\end{array}$ & $\begin{array}{r}89.5 \\
97.7 \\
104.5\end{array}$ & $\begin{array}{r}94.1 \\
100.0 \\
114.4\end{array}$ & $\begin{array}{l}105.8 \\
100.4 \\
118.8\end{array}$ \\
\hline IIS-35 & $\begin{array}{l}0.0 \\
0.0 \\
0.0\end{array}$ & $\begin{array}{l}39.5 \\
68.2 \\
61.4\end{array}$ & $\begin{array}{l}60.0 \\
79.9 \\
78.9\end{array}$ & $\begin{array}{l}82.2 \\
89.8 \\
88.9\end{array}$ & $\begin{array}{r}90.4 \\
100.0 \\
96.2\end{array}$ & $\begin{array}{l}116.6 \\
123.4 \\
123.1\end{array}$ \\
\hline IIC-35 & $\begin{array}{l}0.0 \\
0.0 \\
0.0\end{array}$ & $\begin{array}{l}17.7 \\
29.7 \\
51.6\end{array}$ & $\begin{array}{l}32.8 \\
57.3 \\
67.0\end{array}$ & $\begin{array}{l}52.1 \\
73.7 \\
83.4\end{array}$ & $\begin{array}{r}65.3 \\
100.0 \\
101.6\end{array}$ & $\begin{array}{r}80.9 \\
112.7 \\
111.7\end{array}$ \\
\hline$|1|-1-35$ & $\begin{array}{l}0.0 \\
0.0 \\
0.0\end{array}$ & $\begin{array}{l}22.5 \\
30.8 \\
43.4\end{array}$ & $\begin{array}{l}43.3 \\
64.1 \\
78.5\end{array}$ & $\begin{array}{l}59.4 \\
88.6 \\
97.2\end{array}$ & $\begin{array}{r}79.2 \\
100.0 \\
107.2\end{array}$ & $\begin{array}{l}102.6 \\
118.3 \\
114.8\end{array}$ \\
\hline$|I|-1-45$ & $\begin{array}{l}0.0 \\
0.0 \\
0.0\end{array}$ & $\begin{array}{l}43.5 \\
53.6 \\
57.4\end{array}$ & $\begin{array}{l}54.5 \\
68.5 \\
72.1\end{array}$ & $\begin{array}{l}65.8 \\
73.6 \\
88.6\end{array}$ & $\begin{array}{r}82.4 \\
100.0 \\
107.7\end{array}$ & $\begin{array}{r}99.9 \\
117.2 \\
122.6\end{array}$ \\
\hline V-35 & $\begin{array}{l}0.0 \\
0.0 \\
0.0\end{array}$ & $\begin{array}{l}55.6 \\
66.7 \\
63.0\end{array}$ & $\begin{array}{l}71.6 \\
82.8 \\
80.5\end{array}$ & $\begin{array}{l}89.2 \\
93.7 \\
98.1\end{array}$ & $\begin{array}{r}96.2 \\
100.0 \\
109.3\end{array}$ & $\begin{array}{l}114.9 \\
116.7 \\
126.7\end{array}$ \\
\hline$V-25$ & $\begin{array}{l}0.0 \\
0.0 \\
0.0\end{array}$ & $\begin{array}{l}38.4 \\
46.9 \\
52.0\end{array}$ & $\begin{array}{l}44.6 \\
64.0 \\
69.3\end{array}$ & $\begin{array}{l}55.3 \\
83.0 \\
85.3\end{array}$ & $\begin{array}{r}72.1 \\
100.0 \\
101.7\end{array}$ & $\begin{array}{r}91.9 \\
113.5 \\
117.2\end{array}$ \\
\hline
\end{tabular}

\section{COMENTARIOS}

1) Todos los cementos empleados en este estudio han cumplido con las especificaciones de resistencias mecánicas que se exigen en la norma UNE 80301 . Hay que indicar que deliberadamente no se han realizado ensayos con los cementos a la edad de dos días y sí a la edad de tres debido a que la primera edad a la que se han ensayado los hormigones ha sido esta última, ya que si esta determinación se hacía a la edad de dos días los hormigones no tenían prácticamente tiempo de estar sometidos a las condiciones de temperatura de curado puesto que había que esperar veinticuatro horas antes de proceder al desmoldeo de las probetas y sacarlas de la cámara de curado por lo menos cuatro horas antes de llevar a cabo el ensayo.

\section{COMMENTS}

1) All the cements used in this study have fulfilled the mechanical strength specifications as required by the spanish standard UNE 80 301. It is neccesary to mencion that deliberately there has not been tests on these cements at the age of two days certainly at three days because the first age at which these concretes were tested was the later, since, if this decission was to be done at the age of two days the concretes practically had no time to be subjected to the curing temperatures conditions in as much as to have waited twenty four hours before proceeding to their demolding neither draw them out of the chamber at least four hours before carrying out the test. 
En el cuadro de resistencias de los cementos se observa cómo todos superan las resistencias mínimas exigidas a veinte y ocho días, así como los tipos $\mathrm{V}$ las exigidas a noventa días $y$, sin embargo, ninguno sobrepasa las máximas.

Se observa también que el cemento IIF-35 da prácticamente a todas las edades de ensayo resistencias superiores al cemento tipo 1-45A.

Salvo los cementos mixtos, los demás se aproximan más, por sus resistencias, a cementos de categoría 45 que a la de 35 .

En el cemento tipo V-25 con un 60 por 100 de adiciones, se observa una ganancia muy alta de resistencias entre los 28 y 90 días, pasando de 30 a $44 \mathrm{~N} / \mathrm{mm}^{2}$, lo que indica que una gran parte de la actividad puzolánica de las cenizas que llevaba como adición se ha desarrollado entre esas dos edades.

2) Las cantidades de agua de amasado requeridas por los hormigones fabricados con los ocho cementos diferentes para conseguir las mismas consistencias son muy parecidas entre sí como puede observarse en el cuadro apreciándose una disminución del agua en los hormigones confeccionados con los cementos tipo V.

3) La ganancia de resistencias a compresión con el tiempo de los hormigones fabricados con los distintos cementos ha seguido una evolución normal tanto en los hormigones curados en las condiciones normalizadas como en los curados a las temperaturas de $5^{\circ}$ y $35^{\circ} \mathrm{C}$.

Se observa que los hormigones confeccionados con el cemento tipo IIF-35 proporcionan algo más de resistencias a todas las temperaturas de curado que los hormigones hechos con el cemento I-45A. Esto es en cierto modo lógico si se tiene en cuenta que el cemento con adición de filler calizo daba más resistencia que el tipo I.

4) Con respecto a la temperatura de curado se observa que al elevarse ésta, dentro de los márgenes del estudio, aumentan las resistencias de los hormigones; sin embargo, se aprecia que, en general, los incrementos de resistencias son superiores con el paso de $5^{\circ} \mathrm{C}$ a $20^{\circ} \mathrm{C}$ que con el de esta temperatura a $35^{\circ} \mathrm{C}$, hecho que, por otra parte, es lógico si se tiene en cuenta que las temperaturas comprendidas entre $15^{\circ} \mathrm{C}$ y $20^{\circ} \mathrm{C}$ son las que dan lugar a hidrataciones más idóneas.
In the table of strengths of the cements it is observed that all have superated the minimum strength required at twenty eigth days and cement type $V$ at ninety days and none surpassed the maximum strength.

Also it can be noted that in practice the cement IIF-35 have higher strengths than cement type $\mathrm{I}$ in all testing ages.

With the exception of the type $V$ cements the rest of them approximate more to the cements in class 45 than to cements in class 35 in relation with their strengths.

In the cement type V-25 which contain $60 \%$ of additions there is a high increase of strength within 28 and 90 days, passing from $30 \mathrm{~N} / \mathrm{mm}^{2}$ to $44 \mathrm{~N} / \mathrm{mm}^{2}$ which indicates that the greater part of the puzzolanic activity of the fly ashes used as additive had developed within these two ages.

2) The amount of mixing water required in the fabrication of the concretes with the eigth different cements to obtain the same consistence were very much alike as can be noted in the table appreciating a decrease of water in concretes made of cement type 1.

3) The increase of strength with time in those concretes made of different cements and cured at the temperaturess of $5^{\circ} \mathrm{C}$ and $35^{\circ} \mathrm{C}$ has followed a normal evolution similar to concrete cured under normalysed conditions at $20^{\circ} \mathrm{C}$.

It is observed that concretes made of cement type IIF-35 has some more strenths in all curing temperatures than concretes made with cement I-45A. In a certain way this is logical if one takes in account that the cement with limestone filler as additive has more strength than the cement type I.

4) With respect to curing temperature it is observed that when this increases, within the study margin, the strength of the concrete increase. Moreover, in general one appreciiates that these increases in strength are higher on passing from $5^{\circ} \mathrm{C}$ to $20^{\circ} \mathrm{C}$ than in temperature of $35^{\circ} \mathrm{C}$ and act which in other way is logical given that the temperatures embraced between $15^{\circ} \mathrm{C}$ and $20^{\circ} \mathrm{C}$ are the ones which give place to a more suitable hydration. 
5) En cuanto a las resistencias relativas de los hormigones a las distintas edades con respecto a las de 28 días, se observa un crecimiento normal, dando tal vez algo más de crecimiento de resistencias relativas entre las edades de 28 y 90 días los cementos tipo IIZ.

6) La madurez relativa de los hormigones hechos con los diferentes cementos con respecto a la madurez correspondiente a 28 días en curado a $20^{\circ} \mathrm{C}$ no presenta ninguna anormalidad comportandose, por consiguiente, de forma bastante perfecta los distintos hormigones.

7) Las series fabricadas con cada hormigón para cada edad de ensayo han consistido en cuatro probetas y aunque las dispersiones obtenidas dentro de cada serie no han superado el 15 por 100 , por razones diversas, los puntos obtenidos se escapan a veces de lo que sería una curva perfecta; esto es totalmente normal en este tipo de ensayos con hormigón en los que la población de la muestra es reducida.
5) With regard to the relative strengths for the concretes at different ages in relation to 28 days, one observe a normal increase, and perhaps some increase in relative strength between ages of 28 and 90 days in cements type IIZ.

6) The relative maturity of the concretes made of differents cements in respect to the maturity corresponding to 28 days of curing at $20^{\circ} \mathrm{C}$ does not present any anormality, so the distint concretes present a perfect behaviour.

7) The series fabricates with every concrete for every age of test have consisted in four speciments and though the dispersions obtained within each serie have not surpassed 15 per 100, for different reasons the points obtained in the curves in the graphics sometimes escape from what to have been a perfect curve, this is totaly normal in this type of tests where the number of speciments tested is reduced.

\section{monografía del ICCET/CSIC (n. $\left.{ }^{\circ} 402\right)$}

\section{SOL Y VIDRIO}

\section{GLORIA FERNÁNDEZ ARROYO}

Dra. en Ciencias Químicas

Madrid, septiembre 1990

El vidrio se puede obtener a partir de múltiples composiciones, lo que da lugar a propiedades diversas y aplicaciones muy diferentes.

La Monografía consta de cuatro partes. La primera está dedicada a hacer una exposición, no demasiado minuciosa, sobre el vidrio en general.

En la segunda se describe la acción que la radiación luminosa (solar) ejerce sobre diferentes tipos de vidrios. Se hace un estudio de los tres fenómenos principales producidos en el vidrio por efecto de dicha radiación:

- La fluorescencia.

- La solarización.

- El fotocromismo.

La tercera parte hace referencia al aprovechamiento de la radiación solar y el papel que el vidrio tiene en esta captación.

En la cuarta se incluye una recopilación de trabajos de investigación, realizados por la autora, en los que se han preparado diferentes vidrios aplicables como captadores de la Energía Solar. 